\title{
Fetomaternal Effects of TSH Values in the Initial Stage of Pregnancy
}

\author{
๑ Ali Doğukan Anğın ${ }^{1}$, ๑ İsmet Gün ${ }^{1}, \odot$ Yasemin Sevinç ${ }^{1}, \odot$ Önder Sakin ${ }^{1}$, \\ Muzaffer Seyhan Çıkman ${ }^{1}$, $\odot$ Serem Uruş² \\ ${ }^{1}$ Department of Obstetrics and Gynecology, University of Health Sciences Turkey, Dr. Lutfi Kirdar Kartal Training and Research Hospital, \\ Istanbul, Turkey \\ 2Private Held Company, Istanbul, Turkey
}

\begin{abstract}
Introduction: To examine the fetomaternal effects of TSH values considered to be high ( $\geq 2.5 \mathrm{and}<4 \mu \mathrm{lU} / \mathrm{mL})$ during pregnancy. Methods: Pregnant women admitted to the obstetrical outpatient clinic of Istanbul Kartal Training and Research Hospital between January 2017 and December 2017 with TSH values $>0.3$ and $<4 \mu \mathrm{IU} / \mathrm{mL}$ in the first trimester of their pregnancy who were followed up in our clinic until giving birth were included to the study. Patient files were reviewed retrospectively. The 518 patients meeting the criteria were divided into 2 groups according to their initial TSH values; Group 1 consisted of patients with TSH $<2.5 \mu \mathrm{lU} / \mathrm{mL}(\mathrm{n}=410)$, and Group 2 of patients with $\mathrm{TSH} \geq 2.5$ and $<4 \mu \mathrm{lU} / \mathrm{mL}(\mathrm{n}=108)$. Demographic characteristics and poor pregnancy outcomes (PPO) of the patients were compared.

Results: Comparing the demographic characteristics of the two groups formed according to the patients'TSH values at the onset of their pregnancy, no statistically significant differences were found $(p<0.05)$. When the two groups were compared in terms of poor pregnancy outcomes (PPO), no statistically significant difference was found either ( $p=.852 ; \mathrm{OR}$ : 1.067; $\mathrm{Cl}$ : 0.541-2.102).

Discussion and Conclusion: In cases of subclinical hypothyroidism during pregnancy, refraining from medication does not cause PPO.

Keywords: Hyperthyroidism; pregnancy; subclinical; TSH.
\end{abstract}

A mong the most commonly found problems during pregnancy are thyroid disorders. The activity of the thyroid gland and hormone levels change during pregnancy. As the production of thyroid hormones increases, the daily need for iodine rises by around $50 \%{ }^{[1,2]}$. The Turkish Endocrinology and Metabolism Association (TEMD) recommends 100-200 $\mu \mathrm{g}$ daily iodine intake for pregnant women ${ }^{[3]}$.

Due to changes in thyroid metabolism, fetal and maternal adverse consequences such as premature birth, miscarriage, habitual abortus, intrauterine growth retardation, Cesarean section, intrauterine death, infertility, mental retardation, preeclampsia, and diabetes may occur ${ }^{[4,5]}$. Therefore it is vital to detect thyroid diseases during pregnancy. While screening is recommended for high-risk pregnancies in order to prevent possible complications, some studies have emphasized that all pregnant women should

Correspondence (İletişim): Ali Doğukan Anğın, M.D. Saglik Bilimleri Universitesi, Kartal Dr. Lutfi Kirdar Egitim ve Arastirma Hastanesi, Kadin Hastaliklari ve Dogum Klinigi, Istanbul, Turkey Phone (Telefon): +90 5056232027 E-mail (E-posta): ala_2001@hotmail.com 
be screened, while some argued that this approach would not be cost-effective ${ }^{[6,7]}$. Screening during pregnancy is carried out through $\mathrm{TSH}^{[8]}$. There exists no clear consensus on which patients should be screened, the range of reference values, and threshold values in screening.

The aim of this study is to examine the fetomaternal effects of TSH values ( $\geq 2.5$ and $<4 \mu \mathrm{IU} / \mathrm{mL}$ ) that are considered to be within normal limits in non-pregnancy conditions but are considered to be high during pregnancy.

\section{Materials and Methods}

Pregnant women admitted to the obstetrical outpatient clinic of Istanbul Kartal Training and Research Hospital between January 1, 2017 and December 31, 2017 whose TSH values were $>0.3$ and $<4 \mu \mathrm{lU} / \mathrm{mL}$ in the first trimester of their pregnancy and who were followed up and in our clinic during their pregnancy until giving birth, again in our clinic, were included in the study. Patient files were reviewed retrospectively.

Patients with systemic diseases such as overt diabetes, hypertension, systemic lupus erythematosus, and rheumatoid diseases before pregnancy were excluded from the study. Patients with any thyroid disease or using thyroid medication before or during pregnancy were also excluded from the study. A total of 518 patients meeting the criteria were included in the study. They were divided into 2 groups according to their initial TSH values. Group 1 consisted of patients with TSH $<2.5 \mu \mathrm{lU} / \mathrm{mL}(\mathrm{n}=410)$, Group 2 of patients with TSH $\geq 2.5$ and $<4 \mu \mathrm{IU} / \mathrm{mL}(\mathrm{n}=108$ ) (Fig. 1). Cases with TSH values $\geq 2.5$ and $<4 \mu \mathrm{IU} / \mathrm{mL}$ were considered subclinical hypothyroidism. Ethical approval for the study was obtained from the hospital Ethics Committee (2018-514-142-1).

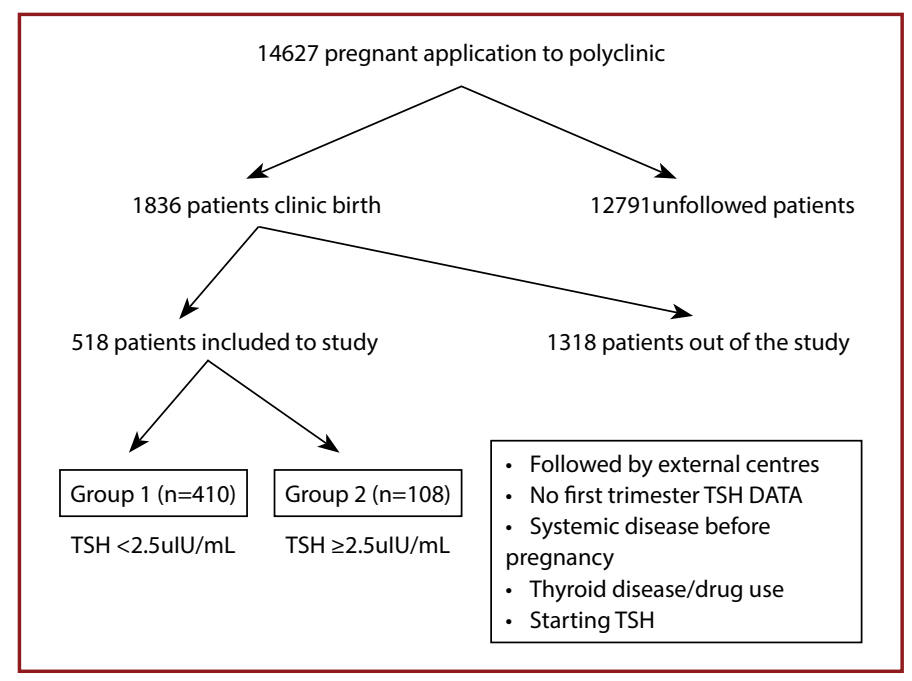

Figure 1. Collective information scheme on patients and groups
Patients' age, gravida, parity, abortion history, gestational week, delivery type, birth weight, neonatal status and hospitalization in intensive care and additional disease conditions developed during pregnancy (gestational diabetes, preeclampsia, fetal growth retardation, gestational cholestasis, dead fetus in utero) were recorded. Pregnancy loss (intrauterine fetal death, stillbirth), neonatal death, preterm birth ( $<34$ weeks of gestation), at least 24 hours of hospitalization in the neonatal intensive care unit after birth, intrauterine growth retardation (IUGR) (lower than the $10^{\text {th }}$ percentile of the expected fetal weight in the calculated gestational week), birth weight of the baby $<2500$ $\mathrm{g}$, hypertension developing during pregnancy (hypertension developing after the second trimester, without proteinuria, normalization of blood pressure values within 12 weeks at the latest postpartum), preeclampsia (hypertension occurring after $20^{\text {th }}$ week of gestation $\left.[\geq 140 / 90)\right]$ and new-onset thrombocytopenia with or without proteinuria, twofold increase in liver enzymes, pulmonary edema, cerebral or visual symptoms), eclampsia (preeclampsia with convulsions) and the development of chronic diseases like gestational diabetes (glucose intolerance at various levels starting/first diagnosed during pregnancy) were evaluated as poor pregnancy outcomes. Patients' demographic characteristics, data such as gestational week, type of delivery, weight of the baby, and poor pregnancy outcomes were compared between the two groups. The existence of at least one of the abovementioned fetomaternal outcomes was considered a poor pregnancy outcome.

\section{Statistical Analysis}

Statistical analysis was conducted using SPSS version 15 (SPSS Inc., Chicago, IL). For continuous data, the statistical analysis was performed by Student's t-test and for categorical by data $x^{2}$ test. Statistical significance was defined as $\mathrm{p}<0.05$.

\section{Results}

Of the 14627 pregnant women presenting to the Kartal Training and Research Hospital's gynecology and obstetrics outpatient clinic between 01 January 2017 and 31 December 2017, 518 women met the criteria and were included in the study. Group 1 consisted of 410 patients and group 2 of 108. The average age of the patients was $29.6 \pm 4.0$ years. Patients' demographic characteristics, data about the birth and the baby and regarding the presence of PPO are shown in Table 1, showing no difference between the groups regarding demographic characters and birth data. The PPO rate is $43 / 367(10.5 \%)$ in group 1 and 12/96 (11.1\%) in 
Table 1. Comparision of demographic data between the groups

\begin{tabular}{lccc}
\hline Parameters & GRUP 1 (n=410) & GRUP 2 (n=108) & P \\
\hline Age (Year) & $29.63 \pm 3.9$ & $29.47 \pm 4.1$ & $0.718^{\mathrm{a}}$ \\
Gravida (n) & $2.91 \pm 1.3$ & $2.81 \pm 1.2$ & $0.512^{\mathrm{a}}$ \\
Parity (n) & $1.52 \pm 0.9$ & $1.53 \pm 1.0$ & $0.919^{\mathrm{a}}$ \\
Abortion (n) & $0.34 \pm 0.7$ & $0.22 \pm 0.5$ & $0.061^{\mathrm{a}}$ \\
Birth Weight (g) & $3329 . \pm 522$ & $3311 \pm 50.1$ & $0.747^{\mathrm{a}}$ \\
Pregnancy Week with Delivery & $38.6 \pm 1.7$ & $38.6 \pm 1.6$ & $0.746^{\mathrm{a}}$ \\
Form of Delivery (NSD/CS) & $260 / 150$ & $77 / 31$ & $0.126^{\mathrm{b}}$ \\
PPO (Yes/No) & $43 / 367$ & $12 / 96$ & $0.852^{\mathrm{b}}$ \\
\hline
\end{tabular}

Data were given as average $\pm \mathrm{SD}$ and $\mathrm{n} ;{ }^{\mathrm{a}}$ : student $\mathrm{t}$ test; ${ }^{\mathrm{b}}: \mathrm{x}^{2}$ test. NSD: Normal spontaneous delivery; CS: Cesarean section; PPO: Poor pregnancy outcomes.

group 2. In the incidence of poor pregnancy outcomes, no statistically significant difference was observed between the two groups ( $p=0.852 ;$ OR: $1.067 ; \mathrm{Cl}: 0.541-2.102$ ) (Table 1). Fetomaternal results for the groups related with TSH values (PPO findings; preterm delivery week, low birth weight, growth retardation, preeclampsia, gestational diabetes and hypertension, stillbirth, admission to neonatal intensive care) are summarized in Table 2.

\section{Discussion}

Although changes in thyroid metabolism during early pregnancy are thought to develop due to the increase in human chorionic gonadotropin hormone levels (Beta HCG) and its TSH-like effect, there are also studies arguing the opposite $^{[9-11]}$. Early screening of thyroid dysfunctions is important because of intrauterine damage, especially in the early gestational weeks, and the protective effect may be higher with early screening ${ }^{[12]}$.
It is TSH recommended for screening at the beginning of pregnancy ${ }^{[13]}$. However, the range of TSH values is controversial, because although normal TSH values vary from one country to another and from society to society, personal iodine deficit, body mass index, age, and the measurement method also affect the results ${ }^{[14]}$. In the 2011 review of the American Thyroid Association (ATA American Thyroid Association), the recommended first trimester TSH value is in the range of $0.1-2.5 \mathrm{mIU} / \mathrm{L}^{[15]}$. In the ATA 2017 review, lower and upper reference values varying in the range of $0.02-4.68 \mathrm{mIU} / \mathrm{L}$ are specified in different studies, and it is emphasized that the reference values will vary from society to society ${ }^{[16]}$. In our study, we included patients with TSH values between $0.3 \mathrm{mIU} / \mathrm{L}$ and $4 \mathrm{mIU} / \mathrm{L}$ living in the Anatolian side of Istanbul. TEMD stated the value range for the $1 \mathrm{st}$ trimester as $0.1-2.5 \mathrm{mU} /$ $\mathrm{mL}$ in the 2017 thyroid diseases diagnosis and treatment guideline $^{[3]}$.

The prevalence of hypothyroidism is $2-3 \%$ for subclinical

Table 2. Distribution of fetomaternal data between groups

\begin{tabular}{|c|c|c|c|}
\hline Parameters & $\begin{array}{c}\text { GROUP } 1 \\
n=410(\%)\end{array}$ & $\begin{array}{c}\text { GROUP } 2 \\
n=108(\%)\end{array}$ & $\mathbf{p}$ \\
\hline Week of delivery <34 week & $7(1.7)$ & $2(1.8)$ & $1.000^{\mathrm{a}}$ \\
\hline$\leq 2500 \mathrm{~g}$ & $26(6.3)$ & $5(4.6)$ & $0.661^{b}$ \\
\hline IUGR* & $9(2.1)$ & $3(2.7)$ & $0.721^{a}$ \\
\hline Preeclampsia & $3(0.7)$ & 0 & - \\
\hline Eclampsia & 0 & 0 & - \\
\hline Gestational diabetes & $5(1.2)$ & $2(1.8)$ & $0.640^{\mathrm{a}}$ \\
\hline Gestational hypertension & $11(2.6)$ & $2(1.8)$ & $1.000^{\mathrm{a}}$ \\
\hline
\end{tabular}

*IUGR: intrauterine growth retardation; **PPO: Poor pregnancy outcomes; ${ }^{\text {a: }}$ Fisher's exact test; ${ }^{\text {b }}$ : chi-square test. 
hypothyroidism during pregnancy whereas it is around $0.3-0.5 \%$ for overt hypothyroidism ${ }^{[3]}$. The incidence of subclinical hypothyroidism among the pregnancies that gave birth in the range of the study dates in our clinic is $5.8 \%$. Although the discussions on the necessity of subclinical hypothyroidism treatment in pregnancy and also the TSH threshold value to be used in screening are not clear, the value of $2.5 \mathrm{mIU} / \mathrm{L}$ has been used in many studies ${ }^{[16-18]}$. TEMD suggested that the TSH level should be kept at $<2.5 \mathrm{mU} / \mathrm{mL}$ before pregnancy and in the first trimester ${ }^{[3]}$. In our study, we also used $2.5 \mathrm{mIU} / \mathrm{L} \mathrm{TSH}$ value while forming the groups. In the last review of ATA, $4.0 \mathrm{mIU} / \mathrm{L}$ was shown as the upper limit ${ }^{[16]}$. Based on 2.5 $\mathrm{mIU} / \mathrm{L}$ in their study Marta et al. ${ }^{[19]}$ found that the rate of perinatal loss, miscarriage, and preterm delivery was high in the group with values between 2.5 and $5.1 \mathrm{mIU} / \mathrm{L}$. Similarly, there are studies not finding significant to use $2.5 \mathrm{mIU} / \mathrm{L}$ as the threshold value and suggesting use of higher limits ${ }^{[20,21]}$. In our study, we found no significant difference between the groups in terms of poor pregnancy outcomes (Table 1).

Some of the poor pregnancy and neonatal outcomes associated with subclinical hypothyroidism are preterm labor, growth retardation, low birth weight, preeclampsia, miscarriage, stillbirth, gestational hypertension and diabetes $^{[22]}$. Although there are studies showing that these effects are related to subclinical hypothyroidism ${ }^{[23-26]}$, there are also studies in the opposite direction stating that they are not related with each other ${ }^{[27-29]}$. In our study, the fetomaternal results we label as PPO and consider to be in relation with the high TSH effect due to subclinical hypothyroidism did not show a significant difference between the two groups.

Suggesting that the majority of pregnant women could be asymptomatic, TEDM recommended TSH screening at their first admission ${ }^{[3]}$. In the latest updated ATA review; oral evaluation of all pregnant women and serum TSH screening are recommended if certain risks are existed. One of these risks is the history of pregnancy loss, preterm birth or infertility ${ }^{[16]}$. In our study, no significant difference was observed when the groups were compared in terms of abortion history (Table 1).

In our study, groups were formed depending upon TSH values only. The lack of evaluation of aTPO antibodies and free T4 values, the low number of group patients, unknown long-term neonatal results, iodine deficiency and not taking ethnic differences into consideration can be listed among the shortcomings of our study.

\section{Conclusion}

As a result; lack of drug use in subclinical hypothyroid pregnant women does not cause PPO. Indeed, in order to determine which patients should be screened, the appropriate reference range and correct threshold values, we consider that it is appropriate to create community-specific screening methods with community-based large-scale studies that taking social and regional changes into account.

Ethics Committee Approval: Ethical approval for the study was obtained from the hospital Ethics Committee (2018-514-142-1).

Peer-review: Externally peer-reviewed.

Authorship Contributions: Concept: I.G., Ö.S.; Design: A.D.A., S.U.; Data Collection or Processing:Y.S.; Analysis or Interpretation: M.S.Ç., S.U.; Literature Search: M.S.Ç., Ö.S.; Writing: A.D.A.

Conflict of Interest: None declared.

Financial Disclosure: The authors declared that this study received no financial support.

\section{References}

1. Koyuncu K, Turgay B, Söylemez F. lodine deficiency in pregnant women at first trimester in Ankara. J Turk Ger Gynecol Assoc 2019;20:37-40. [CrossRef]

2. Stagnaro-Green A, Sullivan S, Pearce EN. lodine supplementation during pregnancy and lactation. JAMA 2012;308:2463-4.

3. http://temd.org.tr/admin/uploads/tbl_kilavuz/ 20180518105146-2018-05-18tbl_kilavuz105136.pdf (erişim 07.11.2018)

4. Šálek T, Dhaifalah I, Langova D, Havalová J. Maternal thyroid-stimulating hormone reference ranges for first trimester screening from 11 to 14 weeks of gestation. J Clin Lab Anal 2018;32:e22405. [CrossRef]

5. Krassas GE, Poppe K, Glinoer D. Thyroid function and human reproductive health. Endocr Rev 2010;31:702-55. [CrossRef]

6. Thung SF, Funai EF, Grobman WA. The cost-effectiveness of universal screening in pregnancy for subclinical hypothyroidism. Am J Obstet Gynecol 2009;200:267.e1-7. [CrossRef]

7. Springer D, Jiskra J, Limanova Z, Zima T, Potlukova E. Thyroid in pregnancy: From physiology to screening. Crit Rev Clin Lab Sci 2017;54:102-16. [CrossRef]

8. Männistö $T$, Surcel HM, Ruokonen $A$, Vääräsmäki $M$, Pouta $A$, Bloigu $A$, et al. Early pregnancy reference intervals of thyroid hormone concentrations in a thyroid antibody-negative pregnant population. Thyroid 2011;21:291-8. [CrossRef]

9. Casey BM. The debate on thyroid screening during pregnancy continues. Obstet Gynecol. 2014 Jul;124(1):8-9. [CrossRef]

10. Vila L, Velasco I, González S, Morales F, Sánchez E, Torrejón S, et al. Controversies in endocrinology: On the need for universal thyroid screening in pregnant women. Eur J Endocrinol 2013;170:R17-30. [CrossRef]

11. Haddow JE, McClain MR, Lambert-Messerlian G, Palomaki GE, 
Canick JA, Cleary-Goldman J, et al; First and Second Trimester Evaluation of Risk for Fetal Aneuploidy Research Consortium. Variability in thyroid-stimulating hormone suppression by human chorionic [corrected] gonadotropin during early pregnancy. J Clin Endocrinol Metab 2008;93:3341-7. [CrossRef]

12. Negro R, Stagnaro-Green A. Clinical aspects of hyperthyroidism, hypothyroidism, and thyroid screening in pregnancy. Endocr Pract 2014;20:597-607. [CrossRef]

13. De Groot L, Abalovich M, Alexander EK, Amino N, Barbour L, Cobin $\mathrm{RH}$, et al. Management of thyroid dysfunction during pregnancy and postpartum: an Endocrine Society clinical practice guideline. J Clin Endocrinol Metab 2012;97:2543-65.

14. Martínez M, Soldevila B, Lucas A, Velasco I, Vila L, PuigDomingo $M$. Hypothyroidism during pregnancy and its association to perinatal and obstetric morbidity: a review. Endocrinol Diabetes Nutr 2018;65:107-13. [CrossRef]

15. American Thyroid Association. 2016 ATA Satellite Symposium: Clinical Guidelines on Management of Hyperthyroidism and Other Causes of Thyrotoxicosis; 2016 ATA Guidelines: Thyroid Disease During Pregnancy. Available at: http://www.thyroid. org/professionals/meetings/spring-2016-satellite/.

16. Alexander EK, Pearce EN, Brent GA, Brown RS, Chen H, Dosiou C, et al. 2017 Guidelines of the American Thyroid Association for the Diagnosis and Management of Thyroid Disease During Pregnancy and the Postpartum. Thyroid 2017;27:315-89.

17. Blatt AJ, Nakamoto JM, Kaufman HW. National status of testing for hypothyroidism during pregnancy and postpartum. J Clin Endocrinol Metab 2012;97:777-84. [CrossRef]

18. Potlukova E, Potluka O, Jiskra J, Limanova Z, Telicka Z, Bartakova J, et al. Is age a risk factor for hypothyroidism in pregnancy? An analysis of 5223 pregnant women. J Clin Endocrinol Metab 2012;97:1945-52. [CrossRef]

19. Hernández M, López C, Soldevila B, Cecenarro L, MartínezBarahona $\mathrm{M}$, Palomera $\mathrm{E}$, et al. Impact of TSH during the first trimester of pregnancy on obstetric and foetal complications: Usefulness of $2.5 \mathrm{mIU} / \mathrm{L}$ cut-off value. Clin Endocrinol (Oxf) 2018;88:728-34. [CrossRef]

20. Carty DM, Doogan F, Welsh P, Dominiczak AF, Delles C. Thyroid stimulating hormone $(\mathrm{TSH}) \geq 2.5 \mathrm{mU} / \mathrm{l}$ in early pregnancy: Prevalence and subsequent outcomes. Eur J Obstet Gynecol
Reprod Biol 2017;210:366-9. [CrossRef]

21. Medici M, Korevaar TI, Visser WE, Visser TJ, Peeters RP. Thyroid function in pregnancy: what is normal? Clin Chem 2015;61:704-13. [CrossRef]

22. Maraka S, Ospina NM, O'Keeffe DT, Espinosa De Ycaza AE, Gionfriddo MR, Erwin PJ, et al. Subclinical Hypothyroidism in Pregnancy: A Systematic Review and Meta-Analysis. Thyroid 2016;26:580-90. [CrossRef]

23. Korevaar TI, Schalekamp-Timmermans S, de Rijke YB, Visser WE, Visser W, de Muinck Keizer-Schrama SM, et al. Hypothyroxinemia and TPO-antibody positivity are risk factors for premature delivery: the generation R study. J Clin Endocrinol Metab 2013;98:4382-90. [CrossRef]

24. Liu H, Shan Z, Li C, Mao J, Xie X, Wang W, et al. Maternal subclinical hypothyroidism, thyroid autoimmunity, and the risk of miscarriage: a prospective cohort study. Thyroid 2014;24:1642-9. [CrossRef]

25. Feldthusen AD, Larsen J, Pedersen PL, Toft Kristensen T, Kvetny J. Pregnancy-induced alterations in mitochondrial function in euthyroid pregnant women and pregnant women with subclinical hypothyroidism; relation to adverse outcome. J Clin Transl Endocrinol 2013;1:e13-e17. [CrossRef]

26. Chen LM, Du WJ, Dai J, Zhang Q, Si GX, Yang H, et al. Effects of subclinical hypothyroidism on maternal and perinatal outcomes during pregnancy: a single-center cohort study of a Chinese population. PLoS One 2014;9:e109364. [CrossRef]

27. Männistö T, Vääräsmäki $M$, Pouta $A$, Hartikainen $A L$, Ruokonen $A$, Surcel $H M$, et al. Perinatal outcome of children born to mothers with thyroid dysfunction or antibodies: a prospective population-based cohort study. J Clin Endocrinol Metab 2009;94:772-9. [CrossRef]

28. Sahu MT, Das V, Mittal S, Agarwal A, Sahu M. Overt and subclinical thyroid dysfunction among Indian pregnant women and its effect on maternal and fetal outcome. Arch Gynecol Obstet 2010;281:215-20. [CrossRef]

29. Männistö $T$, Vääräsmäki $M$, Pouta $A$, Hartikainen $A L$, Ruokonen A, Surcel HM, et al. Thyroid dysfunction and autoantibodies during pregnancy as predictive factors of pregnancy complications and maternal morbidity in later life. J Clin Endocrinol Metab 2010;95:1084-94. [CrossRef] 